\title{
COVID-19 Spread Through Petting - A Review
}

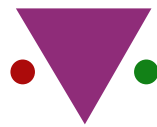

IJCRR

Section: Healthcare

Sci. Journal Impact

Factor: 6.1 (2018)

ICV: 90.90 (2018)

(c) (1) (9)

Copyright@IJCRR

\section{Karthik V. ${ }^{1}$, Leslie Rani ${ }^{2}$, Brundha M. P. ${ }^{3}$}

Saveetha Dental College, Saveetha Institute of Medical and Technical Sciences, Saveetha University, Chennai, Tamil Nadu, India; ${ }^{2}$ Department of General Pathology, Saveetha Dental College, Saveetha Institute of Medical and Technical Sciences, Saveetha University, Chennai, Tamil Nadu Chennai, India; ${ }^{3}$ Associate Professor, Department of General Pathology, Saveetha Dental College, Saveetha Institute of Medical and Technical Sciences, Saveetha University, Chennai, Tamil Nadu Chennai, India.

\section{ABSTRACT}

Aim and Objective: The main aim of this study is to analyse whether COVID 19 can spread through pet animals to humans.

Background and Discussion: Coronavirus belongs to the RNA group of family viruses. Coronaviruses can cause cold-like illness in people and some might cause illnesses in certain animals. Certain viruses like canine and feline coronavirus affect or infect only animals and do not infect humans. Certain coronavirus which infects animals can sometimes spread to humans. This caused an impact on the current issue of the outbreak of COVID-19. COVID 19 spreads primarily from person to person but also there's a chance that it might spread from people to animals or vice versa. Certain studies show that people who are infected but don't have symptoms most likely play a role in the spread of coronavirus. The risk of animals spreading COVID-19 to people is considered to be low severe acute respiratory syndrome and Middle East respiratory syndrome are some examples of disease caused by a coronavirus.

Conclusion: This review discussed the nature of COVID-19 viral spread through domestic pet animals and there is no evidence to suggest that any animals including pets or livestock can spread COVID infection to people.

Key Words: COVID, Dog, Cat, Petting, Spread, Zoonotic infections

\section{INTRODUCTION}

Coronaviruses belong to a large RNA group of family viruses. It causes illnesses like cold like flu in people ${ }^{1}$. While some other coronaviruses cause illness in certain types of animals, such as cattle, dogs, and bats ${ }^{2}$. Certain viruses like canine and feline coronavirus infect only animals and do not infect humans ${ }^{3}$. The first infections were discovered in the animal market, but the virus spreads disease from person to person ${ }^{4}$. The virus that causes COVID-19 spread mainly from person to person through respiratory droplets ${ }^{5}$. Certain studies showed that people who are infected but do not show symptoms, likely also play a role in spreading the COVID virus ${ }^{6}$. The risk of animals spreading COVID-19 to people is considered to be low severe acute respiratory syndrome and the Middle East respiratory syndrome are some examples of disease caused by coronavirus ${ }^{7}$. Environmental contamination through surfaces appears to be a secondary route of transmission and the virus survives mostly on smooth surfaces, such as countertops and doorknobs. Porous materials, such as pet fur, tend to absorb and trap pathogens, making it harder to contact them through touch ${ }^{8}$. There is no sufficient evidence that pets can spread the virus that causes COVID-19 to people ${ }^{9}$. Cats are mostly infected with the coronavirus that causes COVID-19 and easily transmit it to other cats, but dogs are not really susceptible to the infection. A case of SARS-Cov-2, the virus that causes COVID-19 in humans, was diagnosed in a tiger at Bronx Zoo on April $5^{10}$. The first publicly recorded instance of a pet diagnosed with COVID-19 happened in Hong Kong in late February, and Hong Kong's Agriculture, Fisheries and Conservation Department along with expert veterinary doctors at the World Organization for Animal Health concluded it to be a case of human-to-animal transmission ${ }^{11}$. It is advisable that pet owners and veterinarians strictly observe hand washing and other infection control measures as outlined by the CDC when handling the humans ${ }^{12}$. The pet dog belongs to someone who had the virus, so it is believed that the dog contracted the virus from its owner ${ }^{13,14}$. A case in New York showed the cat's owner had diagnosed positive for COVID-19, then it started to spread to humans without any symptoms then it

\section{Corresponding Author:}

M. P. Brundha, Associate Professor, Department of General Pathology, Saveetha Dental College, Saveetha Institute of Medical and Technical Sciences, Saveetha university, Chennai, Tamil Nadu, Chennai, India; Phone: 9884421482; Email: generalpath2015@gmail.com

ISSN: 2231-2196 (Print)

Received: 15.08 .2020
ISSN: $0975-5241$ (Online)

Revised: 12.09 .2020
Accepted: 14.10 .2020

Published: 03.11 .2020 
should be an asymptomatic carrier ${ }^{15}$. It has been suggested that some groups of domestic animals can be infected with the SARS-COV-2 in laboratory settings ${ }^{16}$. Pets fur was one of the modes of spread, previously believed but there is no evidence showing the spread ${ }^{17}$. Currently, there are no reported cases of people catching the coronavirus from animals ${ }^{18}$. If the owner of the pet seems positive to COVID, CDC prefers to isolate the owner from their pets ${ }^{19}$.

\section{Risk of animals spreading virus that causes CoVID19 to humans}

In the Bronx zoo, four tigers and three lions have tested positive for the virus that causes COVID- $19^{20}$. Primarily from person to person but also there is a chance that it can spread from animals to people or people to animals ${ }^{21}$. Different animals were affected by COVID-19. Both wild and domestic cats had been known to be susceptible to feline coronavirus ${ }^{22}$. Chinese study shows that cats are able to infect each other ${ }^{23}$. Fomite infection is any inanimate object that is contaminated or infected with infectious agents that can transfer disease to the new host ${ }^{24}$. Cough can distribute virus particles on animal fur ${ }^{25}$. Severe Acute Respiratory Syndrome (SARS) and MERS are caused by corona to animals and may spread from animal to person ${ }^{26}$. The first infection was infected in animals in the animal market spreading from people to people ${ }^{27}$. There is no sufficient evidence that pets spread coronavirus to people ${ }^{28}$. No evidence of animals that play a major role in spreading COVID-19. No direct evidence that cats spread COVID to other cats ${ }^{26}$. Cats and dogs should be prevented from contacting the infected owner. Viral RNA exposed cats, virus droplets spread from breath out of infected cats. CDC mainly focuses on the control and reduces the risk of COVID-19 transmission ${ }^{29}$. SARS-COV related coronavirus causes severe acute respiratory syndrome and causes widespread to house cats to humans. Some concern that COVID-19 can be spread prior to the development of symptoms but this is not confirmed.

\section{Mode of transmission}

The transmission of this disease is through the respiratory droplets which are packed with the virus particles, spread from the infected patients to other people or to animals ${ }^{30}$, who are infected through the cough or sneezes of the infected people which leads to the mode of transmission. There are no specific antibiotics described for the virus. The affected patients need to get supportive care to breathe. There is no specific vaccine updated for this disease ${ }^{31}$. The corona virology is the science which has been advanced significantly for the past few years. SARS epidemic is an animal coronavirus which was now spotlighted ${ }^{32}$. Coronavirus is associated with both upper and lower respiratory tract. CDC provides the use of standards that shows the contact through airborne and the given particular precautions as prevention from the hospitalized patients thus the preventive measures have to be followed ${ }^{33}$.

\section{Zoonotic infections}

Table 1: The infection which had been recorded the spread from animals to humans ${ }^{33}$.

\begin{tabular}{ll} 
Host & Infections \\
chimpanzee & Ebola virus \\
Vampire bats & Rabies \\
Fruit bats & Nipah virus \\
Migratory Birds & Avian influenza \\
Fox & Rabies \\
Antelope & Rift valley fever \\
Masked palm civets & SARS \\
Turtles & salmonellosis \\
Snake & E.coli \\
Pig & Nipah virus \\
Monkey & Monkeypox \\
Rabbits & Tularemia \\
Prairie dogs & plague \\
Rat & Hantavirus \\
African Squirrel & Monkeypox \\
crow & West nile \\
\hline
\end{tabular}

\section{Stay healthy around animals}

No evidence that animals play a significant role in the spread of coronavirus ${ }^{34}$. All animals can carry the germs that can make people sick. CDC trying to minimize the number of animals getting infected with the virus ${ }^{35}$. Animals were deliberately given high care because of the virus spreading to pet animals like cats and dogs, because they are in close contact. humans lockdown Wuhan, china had been reported that many pet owners had abandoned their pet animals ${ }^{36}$. Relied on them for care and safety measures, pets adoption may raise an impact of coronavirus on animals especially cats and dogs. Only limited data is available for potential SARSCOV-2 infection world wide ${ }^{37}$. A previous study shows a low level of infection with the virus. Certain dog owners in the USA kept their dog in quarantine for a few days. A german shepherd tested positive for infection with SARS-COV $2{ }^{38}$.

\section{People guidance}

Veterinarians always question whether pets' health gives the owner a guide to spread infection. Practice good and proper pet hygiene and clean the pets up properly ${ }^{39,40}$. Many efforts are taken to prevent SARS-COV-2 spread among the cats and to eliminate it. Infected cats produce antibodies against 
SARS-COV-2. The SARS pandemic about SARS-COV is recorded widespread among the house cats ${ }^{41}$. Viral SARSCOV-2 RNA remains vital in the feces and vomit of domestic cats ${ }^{42}$ where the cats have been presented with respiratory and digestive symptoms. The animals owners who are involved in tufts study helps scientists to better understand the spread ${ }^{43}$. The limitations found were, this study mainly focused on the coronavirus spread due to petting animals like cats, dog, etc. It hasn't included domestic animals and birds ${ }^{44}$. This study is conducted with particular geographical areas where pet animals are frequently spotted ${ }^{45}$ where it does not include the virus control and other ways of spreading ${ }^{46}$. Reviews have not focused on the spread of the virus from humans to animals. Only limited information is available upto-date.

\section{CONCLUSION}

This review is necessary as of now since the prevalence of COVID-19 is almost gone to a hedge. The mortality rate seems to be high in the case of COVID-19 when compared to other pandemic issues. The only way to control the mortality rate is to prevent and control its widespread. Recent reviews have revealed that viruses are transferred from people to animals in some situations. Infected animals also show the same symptoms like respiratory illness. At this time there is no evidence to suggest that any animals including pets or livestock can spread COVID infection to people. In this rapidly evolving situation, this review helps to control and prevent the spread of COVID.

\section{ACKNOWLEDGMENT}

Authors acknowledge the immense help received from the scholars whose articles are cited and included in references to this manuscript. The authors are also grateful to authors / editors / publishers of all those articles, journals, and books from which the literature for this article has been reviewed and discussed.

\section{Conflict of Interest: Nil}

Source of Funding: Nil

\section{REFERENCES}

1. Thanh Le T, Andreadakis Z, Kumar A, Gómez Román R, Tollefsen S, Saville M, et al. The COVID-19 vaccine development landscape. Nat Rev Drug Discov [Internet]. 2020 May;19(5):305-6. Available from: http://dx.doi.org/10.1038/d41573-020-00073-5

2. Xu Z. Can common coronavirus compete with novel coronavirus? [Internet]. Available from: http://dx.doi.org/10.31219/osf. io/drtgp
3. Huang Y. In silico analysis of a novel human coronavirus, coronavirus HKU1 [Internet]. Available from: http://dx.doi. org/10.5353/th_b3979382

4. Klein S. Assessment of the CDC's New COVID-19 Data Reporting [Internet]. Coronavirus Concordance. 2020. Available from: http://dx.doi.org/10.21428/85acfa8f.54acf4dd

5. Hu Z, Yang Z, Li Q, Huang Y. Nomenclature: Coronavirus and the 2019 Novel Coronavirus [Internet]. Available from: http:// dx.doi.org/10.20944/preprints202002.0380.v1

6. Admin S. MDPI: Coronavirus [Internet]. 2020. Available from: http://dx.doi.org/10.14293/s2199-1006.1.sor-med.clhswxm.v1

7. Kulkarni P, Dhanushkodi M. Novel coronavirus severe acute respiratory syndrome-coronavirus 2 (coronavirus disease 2019): We shall overcome! [Internet]. Vol. 0, Indian Journal of Medical and Paediatric Oncology. 2020. p. 0. Available from: http:// dx.doi.org/10.4103/ijmpo.ijmpo_104_20

8. Hogue BG, King B, Brian DA. Antigenic relationships among proteins of bovine coronavirus, human respiratory coronavirus OC43, and mouse hepatitis coronavirus A59 [Internet]. Vol. 51, Journal of Virology. 1984 p. 384-8. Available from: http:// dx.doi.org/10.1128/jvi.51.2.384-388.1984

9. Huang L, Hung M-C, Wagner E. Nonviral Vectors for Gene Therapy [Internet]. Elsevier; 2005. 400 p. Available from: https://play.google.com/store/books/details?id=UgZQT-4_GMEC

10. Vijay R. MERS Coronavirus: Methods and Protocols [Internet]. Humana; 2019. 224 p. Available from: https:// books.google.com/books/about/MERS_Coronavirus. html?hl=\&id=zrIuyQEACAAJ

11. Stalin Raj V, Okba NMA, Gutierrez-Alvarez J, Drabek D, van Dieren B, Widagdo W, et al. Chimeric camel/human heavychain antibodies protect against MERS-CoV infection. Sci Adv [Internet]. 2018 Aug;4(8):eaas9667. Available from: http:// dx.doi.org/10.1126/sciadv.aas9667

12. Bosch BJ, Stalin Raj V, Haagmans BL. Spiking the MERScoronavirus receptor [Internet]. Vol. 23, Cell Research. 2013. p. 1069-70. Available from: http://dx.doi.org/10.1038/cr.2013.108

13. Raj VS, Stalin Raj V, Lamers MM, Smits SL, Demmers JAA, Mou H, et al. Identification of Protein Receptors for Coronaviruses by Mass Spectrometry [Internet]. Coronaviruses. 2015. p. 165-82. Available from: http://dx.doi.org/10.1007/978-1-49392438-7_15

14. Reusken CBEM, Chantal B E, Schilp C, Stalin Raj V, De Bruin E, Kohl RHG, et al. MERS-CoV Infection of Alpaca in a Region Where MERS-CoV is Endemic [Internet]. Vol. 22, Emerging Infectious Diseases. 2016. p. 1129-31. Available from: http:// dx.doi.org/10.3201/eid2206.152113

15. Widagdo W, Okba NMA, Stalin Raj V, Haagmans BL. MERScoronavirus: From discovery to intervention [Internet]. Vol. 3, One Health. 2017. p. 11-6. Available from: http://dx.doi. org/10.1016/j.onehlt.2016.12.001

16. Lu R, Zhao X, Li J, Niu P, Yang B, Wu H, et al. Genomic characterisation and epidemiology of 2019 novel coronavirus: implications for virus origins and receptor binding. Lancet [Internet]. 2020 Feb 22;395(10224):565-74. Available from: http://dx.doi. org/10.1016/S0140-6736(20)30251-8

17. Liu P, Chen W, Chen J-P. Viral Metagenomics Revealed Sendai Virus and Coronavirus Infection of Malayan Pangolins (). Viruses [Internet]. 2019 Oct 24;11(11). Available from: http:// dx.doi.org/10.3390/v11110979

18. Gupta N, Agrawal H. COVID 19 and laparoscopic surgeons, the Indian scenario - Perspective. Int J Surg [Internet]. 2020 May 29; Available from: http://dx.doi.org/10.1016/j.ijsu.2020.05.076

19. Jain VK, Vaishya R. COVID-19 and orthopaedic surgeons: the Indian scenario [Internet]. Vol.50, Tropical Doctor. 2020.p. 108-10. 
Available from: http://dx.doi.org/10.1177/0049475520921616

20. V. RP, Ranjith PV, Varma AJ. COVID 19-Indian Scenario, Challenges and Possible Revival Strategies [Internet]. SSRN Electronic Journal. Available from: http://dx.doi.org/10.2139/ ssrn. 3573947

21. Gautam A, Sharma A. Primary Screening of COVID-19 in Indian Scenario: Challenges and Solutions [Internet]. SSRN Electronic Journal. Available from: http://dx.doi.org/10.2139/ssrn.3580045

22. Mp B, Brundha MP, Nallaswamy D. Hide and seek in pathology- A research on game-based histopathology learning [Internet]. Vol. 10, International Journal of Research in Pharmaceutical Sciences. 2019. p. 1410-4. Available from: http://dx.doi. org/10.26452/ijrps.v10i2.606

23. Brundha MP, Pathmashri VP, Sundari S. Quantitative Changes of Red Blood cells in Cancer Patients under Palliative Radiotherapy-A Retrospective Study [Internet]. Vol. 12, Research Journal of Pharmacy and Technology. 2019. p. 687. Available from: http://dx.doi.org/10.5958/0974-360x.2019.00122.7

24. Timothy CN, Samyuktha PS, Brundha MP. Dental pulp Stem Cells in Regenerative Medicine - A Literature Review [Internet]. Vol. 12, Research Journal of Pharmacy and Technology. 2019. p. 4052. Available from: http://dx.doi.org/10.5958/0974360x.2019.00698.x

25. Prashaanthi N, Brundha MP. A Comparative Study between Popplet Notes and Conventional Notes for Learning Pathology [Internet]. Vol. 11, Research Journal of Pharmacy and Technology. 2018. p. 175. Available from: http://dx.doi.org/10.5958/0974360x.2018.00032.x

26. Preethikaa S, Brundha MP. Awareness of diabetes mellitus among general population [Internet]. Vol. 11, Research Journal of Pharmacy and Technology. 2018. p. 1825. Available from: http://dx.doi.org/10.5958/0974-360x.2018.00339.6

27. Kumar MDA, Ashok Kumar MD, Brundha MP. Awareness about nocturia-A questionnaire survey [Internet]. Vol. 9, Research Journal of Pharmacy and Technology. 2016. p. 1707. Available from: http://dx.doi.org/10.5958/0974-360x.2016.00344.9

28. Hannah R, Ramani P, Brundha MP, Herald. J. Sherlin, Ranjith G, Ramasubramanian A, et al. Liquid Paraffin as a Rehydrant for Air Dried Buccal Smear [Internet]. Vol. 12, Research Journal of Pharmacy and Technology. 2019. p. 1197. Available from: http:// dx.doi.org/10.5958/0974-360x.2019.00199.9

29. Shreya S, Brundha MP. Alteration of Haemoglobin Value in Relation to Age, Sex and Dental Diseases-A Retrospective Correlation Study [Internet]. Vol. 10, Research Journal of Pharmacy and Technology. 2017. p. 1363. Available from: http://dx.doi. org/10.5958/0974-360x.2017.00241.4

30. Kalaiselvi R, Brundha MP. Prevalence of hysterectomy in South Indian population [Internet]. Vol. 9, Research Journal of Pharmacy and Technology. 2016. p. 1941. Available from: http:// dx.doi.org/10.5958/0974-360x.2016.00398.x

31. Sowbaraniya SM, Preejitha VB, Brundha MP. Knowledge, awareness, and attitude on dental post-operative complications in diabetes among general population. Drug Invention Today. 2020;13(2).

32. Akshaya R, Preejitha VB, Brundha MP. A survey study of gender-related anxiety and fear on dental care among the patients visiting Saveetha Dental College and Hospital. Drug Invention Today. 2020;13(2).
33. Lakshmi S, Rani SL, Brundha MP. Blow the balloon for the ease--A cross-sectional study on wheezing patients. Drug Invention Today. 2020;14(2).

34. Deepika R, Preejitha VB, Brundha MP. Knowledge and awareness of blood/body fluid spill management among the third year dental students. Drug Invention Today. 2020;14(2).

35. Brundha MP. A Comparative Study-The Role of Skin and Nerve Biopsy in Hansen's Disease. Res J Pharm Biol Chem Sci [Internet]. 2015;7(10):837.

36. Dhivyadharshini J, Brundha MP. Comparison of effects of interpretation of lab reports among the undergraduate dental students. Drug Invention Today. 2020;14(3).

37. Shenoy PB, Brundha MP. Awareness of polycystic ovarian disease among females of age group 18-30 years. Res J Pharm Biol Chem Sci [Internet]. 2016;8(8):813. Available from: http:// search.proquest.com/openview/a8a09e7b2e9d2f967bf3fee479c 7018a/1?pq-origsite $=$ gscholar \&cbl $=54977$

38. Ferdioz J, Brundha MP. Awareness of stye. International Journal of Pharmaceutical Sciences Review and Research [Internet]. 2016 Jan 1 [cited 2020 Jun 6];40(1):30-2. Available from: http:// dx.doi.org/

39. Sarvesh Kumar J, Brundha MP. Awareness about childhood vaccination among parents with children below 15 years of age. Drug Invention Today [Internet]. 2018; Available from: http:// search.ebscohost.com/login.aspx?direct=true\&profile=ehost\&s cope $=$ site \&authtype $=$ crawler $\&$ jrnl $=09757619 \& A N=13244704$ 0\&h=2WpShrfu\%2BS1TcRwVn20QzXQmGi0LTVw8007Sf3e 5Ps0hFqxpLBw\%2Fk91HZB\%2FzP\%2Fw\%2BmIN5YM6Eu4 FTDn8aIdinZg\%3D\%3D\&crl=c

40. Harsha L, Brundha MP. Prevalence of dental developmental anomalies among men and women and its psychological effect in a given population. Res J Pharm Biol Chem Sci [Internet]. 2017;9(6):869. Available from: http://search.proquest. com/openview/1f488cc6e377096f44a87e509aceab79/1?pqorigsite $=$ gscholar \&cbl $=54977$

41. Ravichandran H, Brundha MP. Awareness about personal protective equipments in hospital workers (sweepers and cleaners). International Journal of Pharmaceutical Sciences Review and Research. 2016;40(1):28-9.

42. Balaji S, Brundha MP, Path DNB. Awareness of About Breast Cancer among Dental Surgeons. Res J Pharm Biol Chem Sci [Internet]. 2016;8(8):797. Available from: https://pdfs.semanticscholar.org/63f4/4173d90b35bffa33eed0aeb52ac547ef1567.pdf

43. Akash N, Rani SL, Brundha MP. Awareness on benefits of chia seeds among college students. Drug Invention Today. 2020;14(2).

44. Ananya B, Rani SL, Brundha MP. Knowledge and attitude of probiotics among outpatients visiting dental operatory. Drug Invention Today. 2020;14(2).

45. Naveenaa N, Rani SL, Brundha MP. Knowledge, attitude, and perception on the importance of hematological report among general population. Drug Invention Today. 2020;14(2).

46. Reichal CP, Rani SL, Brundha MP. Occurrence of behavioral changes and its management in persons with mental illness due to lunar effects. Drug Invention Today. 2020;14(2). 